NEWS

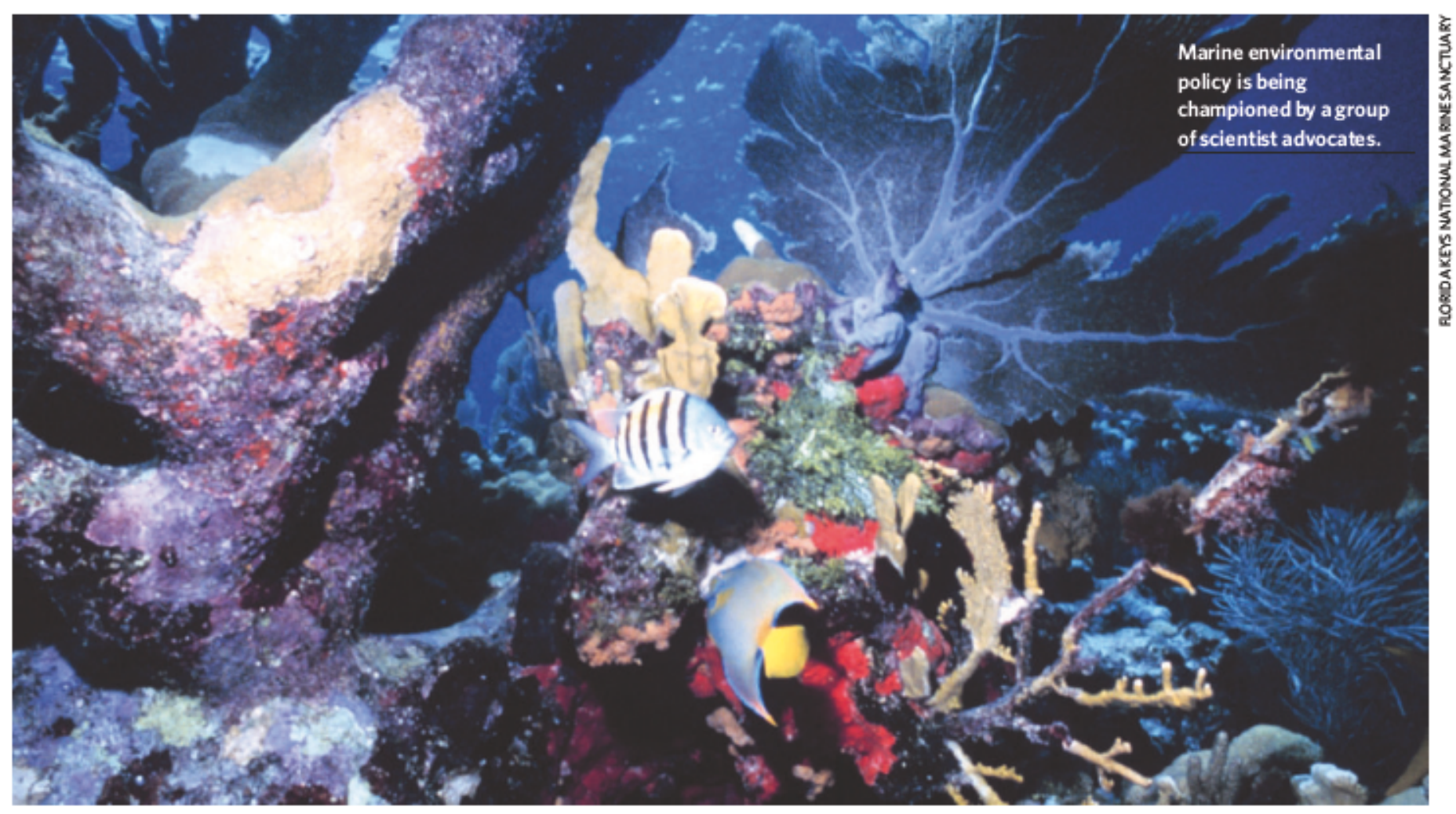

\title{
Scientists unite in bid to drive policy
}

\section{SAN DIEGO}

Tired of having their work ignored by politicians, scientists in the United States are taking matters into their own hands by using political organizations to advance scientific causes.

Political action committees, or PACs, have been around for years in US politics. They are typically used by powerful special-interest groups to collect donations while circumventing the controls on political contributions to specific candidates. But the handful of scienceoriented PACs that have emerged in the past year or so represent a new trend to educate voters and politicians. They are formed by scientists and aim to influence voting or elected officials on specific topics, such as marine environmental policy, stem-cell research or conservation.

Ocean Champions, a California-based organization founded by marine biologist David Wilmot and environmental attorney Jack Sterne, is one example. "In the past, we would watch great science get ignored, manipulated or worse in the political process," says Wilmot, who has worked for several environmental groups. "We would have all our ducks lined up, but in the end we couldn't influence the political decisions. I was tired of losing. We are now using science to create clout to drive good policy."

The PACs are typically targeting US congressional races - although some are already eyeing the 2008 presidential and state elections. And they say they will promote their causes, not any political party. For instance, of the 11 winners among the 14 Senate and House candidates backed by Ocean Champions last year, 6 were Democrats and 5 were Republicans.

Another science-related PAC, StemPAC of Washington DC, was created in July to push stem-cell research StemPAC came out of 'kitchen table talk' by Democratic political consultants concerned about Tay-Sachs disease, for which stem-cell research might lead to therapies. The group jumped immediately into presidential politics by creating advertisements targeting Senator Bill Frist of Tennessee - the Republican majority leader of the Senate, and a physician, who had seemed reluctant to back stemcell research.

The day the advertisements highlighting Frist's opinions were to begin running in New Hampshire, the site of the first presidential primary for the $\mathbf{2 0 0 8}$ election, Frist publicly came out in favour of stem-cell research. Political consultant Bud Jackson, a StemPAC founder, doesn't think the advertisements, which he says never ran, were the main reason Frist changed his mind, but says, "I think we contributed to hastening his decision." Politicians from all parties will be fair game, he adds. "If they are opposed to stem-cell research, we will hit them where it hurts."

StemPAC officials declined to discuss the organization's monetary goals. But at Ocean Champions, Wilmot says the organization aims to raise $\$ 1$ million during the forthcoming two-year federal-election cycle. Last week in Washington, the group held a 'coming-out' fund-raiser to boost its profile. Since forming in 2003 , the group has raised about $\$ 630,000$, Wilmot adds.

Participation in such organizations may be a problem for scientists, many of whom are cautious about leaving the lab for the roughand-tumble world of politics, and worried that their credibility or funding may be affected. "Scientists are afraid of advocacy," says ecologist David Blockstein, senior scientist for the National Council for Science and the Environment in Washington DC. "But this is changing."

Rex Dalton 